\title{
Amino Acid and Carbohydrate Profiles of Rhynchophorus phoenicis (the Larva of Raffia Palm Weevil)
}

\author{
Linda Nnenna Adobeze*, Victor Henry Azubuike Enemor \\ Department of Applied Biochemistry, Faculty of Biosciences, Nnamdi Azikiwe University, Awka, Anambra State, Nigeria
}

\section{Email address:}

1lindachizobam@gmail.com (L. N. Adobeze)

${ }^{*}$ Corresponding author

\section{To cite this article:}

Linda Nnenna Adobeze, Victor Henry Azubuike Enemor. Amino Acid and Carbohydrate Profiles of Rhynchophorus phoenicis (the Larva of Raffia Palm Weevil). American Journal of Health Research. Vol. 8, No. 5, 2020, pp. 89-95. doi: 10.11648/j.ajhr.20200805.13

Received: April 4, 2020; Accepted: April 23, 2020; Published: October 26, 2020

\begin{abstract}
The amino acid and carbohydrate compositions of the larva of the raffia palm weevil were determined in this study. Nutritional components such as amino acid and carbohydrate analyses were carried out on the larva. In the larva, the amino acid profile of the protein and carbohydrate composition was determined using high performance liquid chromatography method. The amino acid composition reveals a total of 18 amino acids with glutamic acid $(14.46 \mathrm{~g} / 100 \mathrm{~g})$ and aspartic acid $(10.65 \mathrm{~g} / 100 \mathrm{~g})$ as the predominant amino acids. The amino acids have a total value of $96.06 \mathrm{~g} / 100 \mathrm{~g}$. The essential amino acids make up $53.08 \mathrm{~g} / 100 \mathrm{~g}$ of the total amino acids. This value represents $55.26 \%$ of the total amino acid composition of the raffia palm weevil sample. The larva of the raffia palm weevil has high values of lysine $(9.72 \mathrm{~g} / 100 \mathrm{~g})$, leucine $(8.98 \mathrm{~g} / 100 \mathrm{~g})$ and arginine $(6.55 \mathrm{~g} / 100 \mathrm{~g})$. The essential amino acids: lysine, leucine, isoleucine, threonine, valine, phenylalanine and tyrosine have higher values than the $\mathrm{FAO} / \mathrm{WHO} / \mathrm{UNU}$ reference values for the respective amino acids. The larva is rich in glucose $(213.96 \mathrm{mg} / 100 \mathrm{~g})$, fructose $(42.47 \mathrm{mg} / 100 \mathrm{~g})$, and sucrose $(36.6 \mathrm{mg} / 100 \mathrm{~g})$. The palm weevil larva represents a very good source of protein, a good complement of essential amino acids, and dietary energy.
\end{abstract}

Keywords: Larva, Protein, Amino Acid, Carbohydrate

\section{Introduction}

The huge Nigeria's livestock resources revealed that the bulk of animal proteins are from cattle, sheep, goat and poultry which are characterized by low productivity, high risk of diseases, and poor genetic potentials [1]. The acute shortage of animal protein sources has been attributed to the phenomenal rise in the prices of conventional animal protein sources such as meat, milk and egg. This therefore calls for the need to research into other animal protein sources such as snails, cane rats, quail and insects that presently seem to be of lesser importance to man [1].

Edible insects can also be sources of micronutrients, and most importantly, of protein, they are often overlooked because of the general negative perceptions on entomophagy [2]. In Indonesia, the Papua Province is located in the easternmost part of the country. The Province is divided into lowlands consisting of sago and mangrove forests, grasslands, and swamps in the coastal areas, and upland areas with primary and secondary forests, and farmed plots. Due to limited agricultural resources in the area, insects, especially grasshoppers, leaf and stick insects, cicadas and large moths and their caterpillars, remain as important protein sources in the people's daily diet [3].

Rhynchophorus phoenicis (palm weevil) is a common pest of raphia palm and larva of this beetle is consumed as food among the many communities in Nigeria and around the world, especially in those places where palm (oil, raphia and coconut) are cultivated on commercial basis [4, 5]. The larvae feed only on decaying organic matter (palm logs, manure and rubbish dumps). Grubs of the raphia palm weevil are fried and eaten in several parts of western Nigeria, in Edo, Delta and Anambra States [1]. Active marketing of the fried grubs takes place in these states. Some families make a fairly good living from selling edible insects and their larvae. They are sold widely in the markets, restaurants and highways. The larva of Rhynchophorus phoenicis can be seen hawked along major roads and markets in Edo and Delta States of Nigeria [6], and constitutes a very large market and dependable income earner along major roads at Oba, Anambra State, 
Nigeria. From Sapele where it is called edible worm or maggot, to Warri, down to Bayelsa, Rivers, Cross River, Akwa Ibom and all the Eastern States of Nigeria, it is widely consumed either raw, boiled, fried, smoked and sometimes used in the preparation of stews and soups, as part of a meal or as a complete meal. Some insect larvae are also believed to possess medicinal properties [7]. In Ogoni Land, the larva of Rhynchophorus phoenicis is used to treat cough in children. Due to the high level of consumption of this larva in these areas, it has become pertinent to scientifically evaluate the nutritional relevance of the larva and consequently proffer advice on possible optimization of its nutritional and/or medicinal potentials.

\section{Materials and Methods}

\subsection{Sample Collection}

Live larvae of Rhynchophorus phoenicis was purchased fresh from local palm wine tappers who harvested them from pest-infested and felled raphia palm trees in Oba town and was identified in the Department of Zoology, Nnamdi Azikiwe University, Awka, Anambra State, South-East of Nigeria. They were transported to the laboratory together with their wet/moist feed of raphia palm pit in a well ventilated container and were used within 24hours of collection.

\subsection{Preparation of Sample}

The harvested larvae were sorted out from the wet/moist feed of raphia palm pit, cleaned, washed in deionised water and dried in an oven (Plus 11 Oven, Sanyo, Gallenkamp PLC, UK) at $105^{\circ} \mathrm{C}$ for 12 hours. The samples were then milled using a food grinder (Model MX 491 N, National, Sheffield, UK) to pass through a 30 mesh sieve, wrapped in dark polyethylene bags, sealed in a clean dry air-tight container and stored in a refrigerator at $4^{\circ} \mathrm{C}$ prior to analyses.

\subsection{Determination of Amino Acid Profile [8]}

\subsubsection{Preparation of Samples and Standards}

Prior to derivatization, sample proteins were hydrolyzed as follows. A $0.1 \mathrm{~g}$ lyophilized sample was weighed into a $16 \times$ $125 \mathrm{~mm}$ screw-cap Pyrex (Barcelona, Spain) tube, $15 \mathrm{ml}$ of $6 \mathrm{~N}$ hydrochloric acid was added, and the tube was thoroughly flushed with $\mathrm{N}_{2}$, quickly capped, and placed in an oven at $110^{\circ} \mathrm{C}$ for $24 \mathrm{hr}$ [6]. After hydrolysis, the tube contents were vacuum filtered (Whatman number 541, Maidstone, England) to remove solids. The filtrate was made up to $25 \mathrm{ml}$ with water, and an aliquot of this solution was further filtered through a $0.50 \mu \mathrm{m}$ pore-size membrane (Millipore, Madrid, Spain). A standard solution containing $1.25 \mu \mathrm{mol} / \mathrm{ml}$ of each amino acid in $0.1 \mathrm{~N}$ hydrochloric acid was created.

\subsubsection{Derivatization Procedure}

The procedure used was a modification of the method of Elkin and Griffith [9].. A standard solution $20 \mu \mathrm{L}$ of sample solution was pipetted into a $10-\times 5-\mathrm{mm}$ tube and dried in vacuo at $65^{\circ} \mathrm{C}$. To the residue, $30 \mu \mathrm{L}$ of methanol-waterPhenylisothiocyanate $(2: 2: 1[\mathrm{v} / \mathrm{v}])$ was added and then removed in vacuo at $65^{\circ} \mathrm{C}$. Next, $30 \mu \mathrm{l}$ of the derivatizing reagent methanol-water-Phenylisothiocianate (7: 1: $1[\mathrm{v} / \mathrm{v}])$ was added, and the tube was agitated and left to stand at room temperature for $20 \mathrm{~min}$. Finally, the solvents were removed under a nitrogen stream, and the tube was sealed and stored at $4{ }^{\circ} \mathrm{C}$, pending analysis. Prior to injection, 150 $\mu \mathrm{L}$ of diluent consisting of $5 \mathrm{mM}$ sodium phosphate with $5 \%$ acetonitrile was added to each tube.

\subsubsection{Chromatographic Procedure}

Chromatography was carried out at a constant temperature of $30^{\circ} \mathrm{C}$ using a gradient elution. Eluent $\mathrm{A}$ was an aqueous buffer prepared by adding $0.5 \mathrm{ml} / \mathrm{L}$ Triethylamine to $0.14 \mathrm{M}$ sodium acetate and titrated to $\mathrm{pH} 6.20$ with glacial acetic acid; eluent B was acetonitrile-water (60: $40[\mathrm{v} / \mathrm{v}])$. The gradient program is shown in Table 1 .

Table 1. Gradient Program Employed for the Separation of PTC-Amino Acids.

\begin{tabular}{llll}
\hline Time Flow rate & & & \\
\hline (min) & $(\mathbf{m L} / \mathbf{m i n})$ & \% Eluent A & \% Eluent B \\
\hline 0 & 1.0 & 90 & 10 \\
12.0 & 1.0 & 70 & 30 \\
20.0 & 1.0 & 52 & 48 \\
22.0 & 1.0 & 0 & 100 \\
24.0 & 1.0 & 0 & 100 \\
30.0 & 1.5 & 0 & 100 \\
37.0 & 1.0 & 90 & 10 \\
\hline
\end{tabular}

\subsection{Determination of Carbohydrate Composition Using HPLC [10]}

Procedure: Two grams $(2 \mathrm{~g})$ of sample was weighed into thick-walled glass digestion tubes, $2 \mathrm{ml}$ of $1 \%$ acetic acid solution was added, and the mixture was vortexed until it formed a consistent gel. It was hydrolyzed following the addition of $10 \mathrm{ml}$ concentrated $\mathrm{HCl}(12 \mathrm{M})$ and heated at $\left(105^{\circ} \mathrm{C}\right)$. After a designated period of hydrolysis, the digestion mixture was cooled to room temperature. To neutralize the hydrolysate, $1 \mathrm{ml}$ was transferred into a mixture of sodium borate $(3.8 \mathrm{~g})$ and deionized (DI) water $(30 \mathrm{ml}), \mathrm{pH}$ adjusted to 7.00 with $10 \mathrm{M}$ $\mathrm{HCl}$, and the solution volume adjusted to $50 \mathrm{ml}$ using $0.2 \mathrm{M}$ borate buffer, $\mathrm{pH}$ 7.0. The derivatization was carried out by mixing $1 \mathrm{~m}$ of the neutralized hydrolysate with $1 \mathrm{~mL}$ of $10 \mathrm{mg} / \mathrm{ml}$ N-(9-Fluorenylmethoxycarbonyloxy) succinimide) (FMOC$\mathrm{Osu}$ ) in acetonitrile and the reaction allowed to progress to completion at ambient temperature for at least 4 hours without agitation.

\subsection{HPLC Analysis}

HPLC analysis was conducted using an Agilent 1100 system equipped with degasser, quaternary pump, auto sampler, and photodiode array detector. Agilent Zorbas SB-C18, 5 $\mu \mathrm{m}, 150$ $\mathrm{mm} \times 4.6 \mathrm{~mm}$ column was used for the chromatography. The elution gradient begins at $70 \%$ of $0.05 \%$ trifluoroacetic acid (TFA) in water (A) and 30\% acetonitrile (CAN) (B). After 6 
minutes, $\mathrm{B}$ is elevated to $100 \% \mathrm{ACN}$ in 5 minutes. The elution rate was held at $0.8 \mathrm{ml} / \mathrm{min}$ and the injection volume was $10 \mu \mathrm{l}$ for both samples and standards. The chromatogram was recorded at $265 \mathrm{~nm} \mathrm{UV}$, integrated, and analyzed with Agilent Chemstation.

\subsection{Statistical Analysis}

Duplicate determinations were carried out on each sample $(\mathrm{N}=2)$, and SPSS Microsoft Excel package was used in analyzing the data. All data were expressed as Mean \pm SEM (standard error of mean).

\section{Result and Discussion}

The amino acid composition of the larvae of raffia palm weevil is presented in figure 1 . The chromatogram of the amino acid profile of the larva of raffia palm weevil revealed a total of 18 amino acids (figure 2). Glutamic acid $(14.46 \mathrm{~g} / 100 \mathrm{~g})$ and aspartic acid $(10.65 \mathrm{~g} / 100 \mathrm{~g})$ were the predominant amino acids (Figure 1). The non-essential amino acid profile showed that the sample investigated contained appreciable quantities of glutamic acid (14.46 g/100g), aspartic acid $(10.65 \mathrm{~g} / 100 \mathrm{~g})$, alanine $(6.29 \mathrm{~g} / 100 \mathrm{~g})$, serine $(4.33 \mathrm{~g} / 100 \mathrm{~g})$, glycine $(4.21 \mathrm{~g} / 100 \mathrm{~g})$, proline $(3.03 \mathrm{~g} / 100 \mathrm{~g})$ and tyrosine $(2.92 \mathrm{~g} / 100 \mathrm{~g})$ respectively.

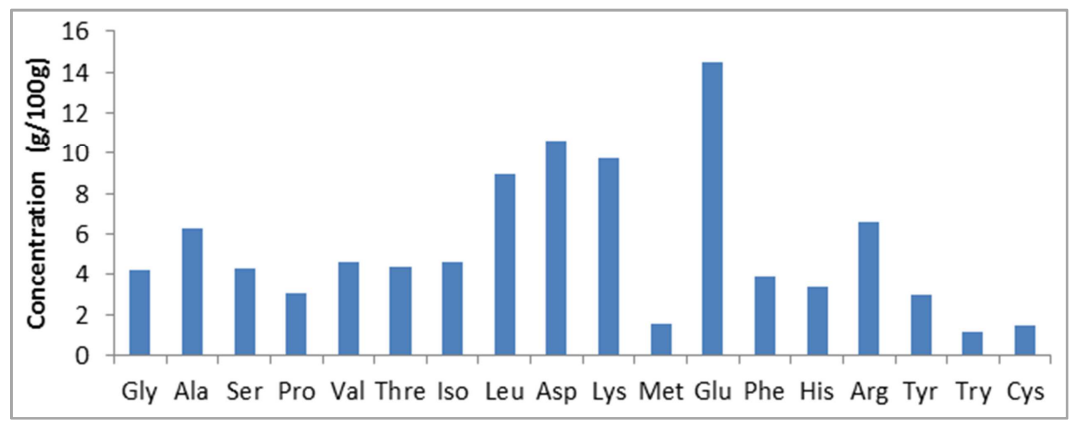

Figure 1. The amino acid composition of the larvae of raffia palm weevil.

Concentrations of these amino acids in the sample compare favourably to those of beef, caterpillar, hen's egg, casein and cow milk as reported by FAO [11]. Among the non-essential amino acids in the samples analyzed, the highest concentration occurred for glutamic acid followed by aspartic acid compared with other amino acids, whereas the lowest value occurred in tyrosine followed by cysteine. A similar trend was reported for beef, caterpillar, whole hen's egg, casein and cow milk [11].

Table 2. Classes of amino acids with their percentage composition.

\begin{tabular}{|c|c|c|c|}
\hline Classes of Amino Acids & Amino Acids & Composition & \% Composition \\
\hline Aliphatic or Neutral & $\begin{array}{l}\text { Glycine + Alanine + } \\
\text { Valine + Leucine + } \\
\text { Isoleucine }\end{array}$ & 28.73 & 29.91 \\
\hline Aromatic & $\begin{array}{l}\text { Phenylalanine }+ \\
\text { Tyrosine }+ \text { Tryptophan }\end{array}$ & 7.95 & 8.28 \\
\hline Hydroxyamino & Serine + Threonine & 8.67 & 9.03 \\
\hline Dicarboxylic or Acidic & Aspartate + Glutamate & 25.11 & 26.14 \\
\hline Basic & $\begin{array}{l}\text { Lycine }+ \text { Arginine }+ \\
\text { Histidine }\end{array}$ & 19.64 & 20.45 \\
\hline Sulphur-containing & Methionine + Cysteine & 2.92 & 3.04 \\
\hline \multirow[t]{2}{*}{ Imino Acids } & Proline & 3.03 & 3.15 \\
\hline & Total & 96.05 & \\
\hline
\end{tabular}

Table 3. Comparison of Essential Amino Acid Composition of the Larva of Palm Weevil (Rhynchophorus phoenicis) with FAO/WHO/UNU Reference Values.

\begin{tabular}{llll}
\hline Essential Amino Acids & Concentration & FAO/WHO/UNU (1991) Ref. value & Remark \\
\hline Lycine & 9.72 & 5.8 & Very good \\
Methionine + Cysteine & 2.92 & 2.5 & Very good \\
Threonine & 4.34 & 3.4 & Very good \\
Tryptophan & 1.12 & 1 & Very good \\
Valine & 4.65 & 3.5 & Very good \\
Leucine & 8.98 & 6.6 & Very good \\
Isoleucine & 4.6 & 2.8 & Very good \\
Phenylalanine + Tyrosine & 6.83 & 6.3 & Very good \\
Arginine & 6.55 & - & \\
Histidine & 3.37 & & \\
Total & 53.08 & & \\
\% Total of Amino Acids & 55.26 & & \\
\hline
\end{tabular}




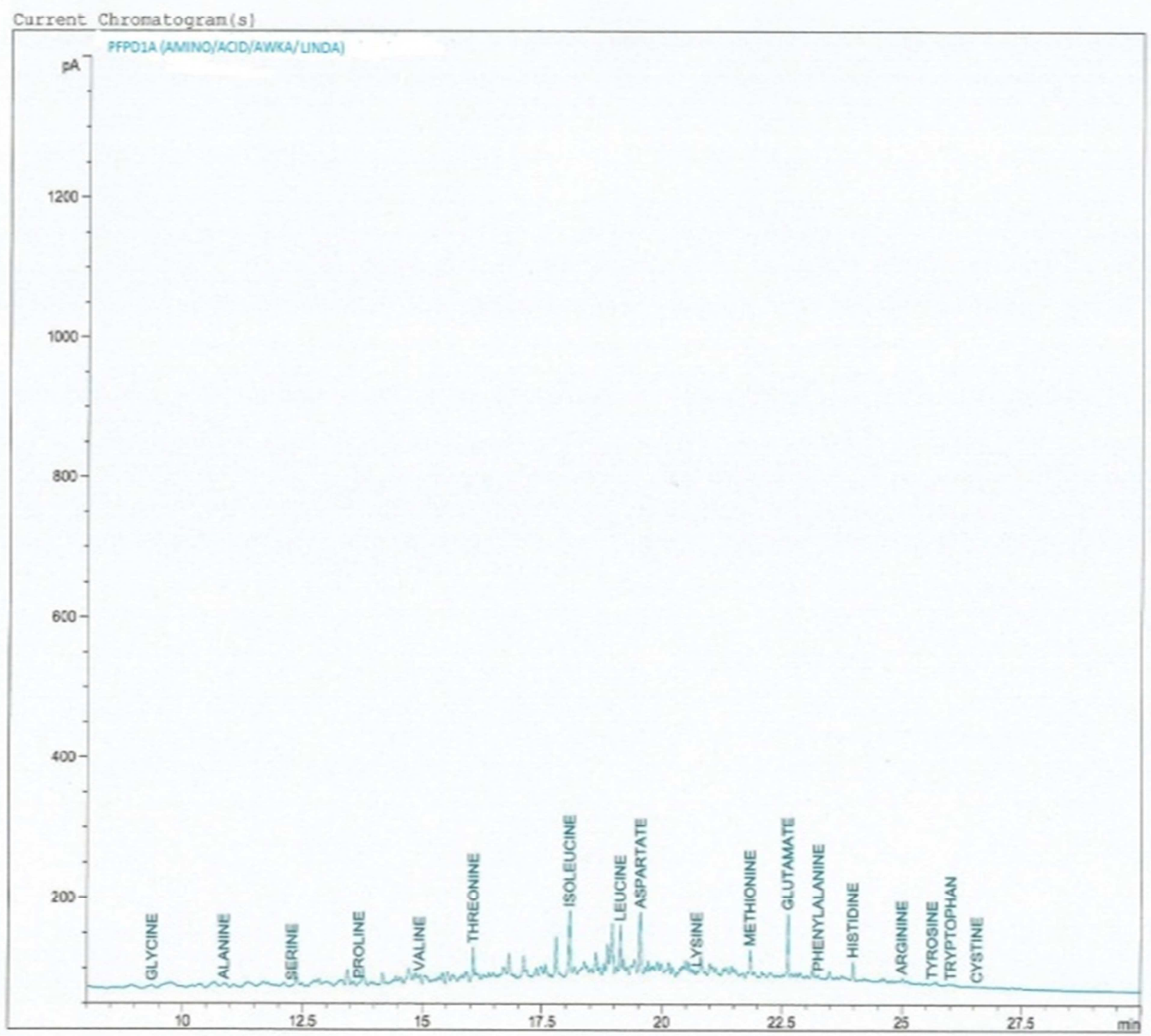

Figure 2. The chromatograms of the amino acid composition of the larva.

Analysis showed that $R$ phoenicis is a good source of the essential amino acids lysine, leucine, arginine, valine, isoleucine, phenylalanine, threonine, histidine and methionine $(9.72,8.98,6.55,4.65,4.60,4.34,3.91,3.37$, and $1.50 \mathrm{~g} / 100 \mathrm{~g}$ ) respectively (Table 3 ). The amino acids have a total value of $96.06 \mathrm{~g} / 100 \mathrm{~g}$. The essential amino acids make up $53.08 \mathrm{~g} / 100 \mathrm{~g}$ of the protein. This value represents $55.26 \%$ of the total amino acid in the specimen. This value is an indication that the larva is a good source of amino acid. In a study on mice by Romano et al. [12], it was concluded that the ratio among EAA and NEAA is the most probable factor responsible for the health-promoting effects of proteins, and that the higher the ratio (closer to 1 or even greater than 1 if supplemented with additional EAA) in the diet, the more efficient it is to increase the lifespan of people suffering from malnutrition.

The larva of the raffia palm weevil has high values of lysine $(9.72 \mathrm{~g} / 100 \mathrm{~g})$, leucine $(8.98 \mathrm{~g} / 100 \mathrm{~g})$ and arginine
$(6.55 \mathrm{~g} / 100 \mathrm{~g})$. The larva also has appreciable values of threonine $(4.34 \mathrm{~g} / 100 \mathrm{~g})$, valine $(4.65 \mathrm{~g} / 100 \mathrm{~g})$, leucine $(8.98$ $\mathrm{g} / 100 \mathrm{~g})$, phenylalanine $(3.91 \mathrm{~g} / 100 \mathrm{~g})$, arginine $(6.55 \mathrm{~g} / 100 \mathrm{~g})$, histidine $(3.37 \mathrm{~g} / 100 \mathrm{~g})$ and lysine $(9.72 \mathrm{~g} / 100 \mathrm{~g})$ when compared to reported values of threonine $(4.00 \mathrm{~g} / 100 \mathrm{~g})$, valine $(5.70 \mathrm{~g} / 100 \mathrm{~g})$, leucine $(8.40 \mathrm{~g} / 100 \mathrm{~g})$, phenylalanine $(4.00 \mathrm{~g} / 100 \mathrm{~g})$, arginine $(6.61 \mathrm{~g} / 100 \mathrm{~g})$, histidine $(2.90 \mathrm{~g} / 100 \mathrm{~g})$ and lysine $(8.40 \mathrm{~g} / 100 \mathrm{~g})$ for beef meat [13] as well as the values of lysine $(7.40 \mathrm{~g} / 100 \mathrm{~g})$, threonine $(4.80 \mathrm{~g} / 100 \mathrm{~g})$, valine $(5.40 \mathrm{~g} / 100 \mathrm{~g})$, leucine $(8.40 \mathrm{~g} / 100 \mathrm{~g})$, phenylalanine $(3.50 \mathrm{~g} / 100 \mathrm{~g})$, arginine $(7.50 \mathrm{~g} / 100 \mathrm{~g})$ and histidine $(2.10$ $\mathrm{g} / 100 \mathrm{~g}$ ) for goat meat [13]. The values imply that the larva of raffia palm weevil is a very good source, comparable to legumes, goat and beef meats in the supply of essential amino acids.

The branched chain amino acids; valine, leucine and isoleucine make up $18.23 \mathrm{~g} / 100 \mathrm{~g}$ of the protein. These three essential amino acids make up about one third of the skeletal 
muscles in human body.

The sulphur-containing amino acids; methionine and cysteine make up $2.92 \mathrm{~g} / 100 \mathrm{~g}$ protein of the Raffia Palm Weevil Larva. Methionine assists in the breakdown of fats and thus prevents the build-up of fat in the arteries. The high contents of lysine and threonine in $R$ phoenicis are of nutritional significance since these amino acids are usually limiting in most cereals and legumes. Another limiting amino acid, tryptophan, is also present in very low concentration $(1.12 \mathrm{~g} / 100 \mathrm{~g})$. The presence of these amino acids in high concentrations would thus enhance the utilization of the sample investigated (larva of weevils) in the supplementation of cereal diets which are poor in these amino acids.

Protein quality is usually assessed by comparing its essential amino acids content with reference standard ideal protein set by the World Health Organization [14], which is based on the amino acids need for the children aged 2- 5 years. The amino acid score of the larvae of raffia palm weevil was compared with $\mathrm{FAO} / \mathrm{WHO} / \mathrm{UNU}$ reference standard and the result showed that lysine $(9.72 \%)$, leucine $(8.98 \%)$, threonine $(4.34 \%)$, valine $(4.65 \%)$, isoleucine $(4.6 \%)$, phenylalanine + tyrosine $(6.83 \%)$ score higher than their respective reference standards (Table 3). However, the value for methionine + cysteine, and isoleucine contents of the larva of raffia palm weevil are higher than the recommended amino acids requirements $(4.6 \mathrm{~g} / 100 \mathrm{~g}$ protein) for infants, pre-school children between the age of $2-5$ years, school children between the age of $10-12$ years and the adults [15]. Likewise, the leucine content is adequate for both infants, preschool children between the age of $2-5$ years, school children between the age of $10-12$ years and the adults [15]. These amino acids are found to be higher than $1.9 \mathrm{~g} / 100 \mathrm{~g}$ protein set as reference standard [14]. This implies that the amino acids composition in the larva of raffia palm weevil has a high biological value and could contribute in meeting the human requirements for these essential amino acids.

Histidine and arginine are also essential for children and infants. Histidine is essential for infants and small children (decreasingly with age), while arginine is made by the body at all ages, only at a slower rate in the early years. In the fight against malnutrition, there are three possible options: fortification, supplementation and dietary diversification. Among the three, dietary diversification is viewed as most sustainable [3]. In promoting this option, the FAO encourages people to utilize indigenous fruits and vegetables to increase the nutrients in their diet. $R$. phoenicis larva is thus a good source of essential amino acids and highly nourishing sample of high availability, therefore its propagation and utilization should be encouraged in Nigeria and other neighboring countries where they are endemic, and where malnutrition is also prevalent. $R$ phoenicis can also be recommended as protein-rich food that could help in solving the problems of protein shortage and its associated nutritional disorders.

The results obtained for the carbohydrate composition showed that the larva is rich in monosaccharide; glucose $(213.96 \mathrm{mg} / \mathrm{g})$ and fructose $(42.47 \mathrm{mg} / \mathrm{g})$, and disaccharide, sucrose $(36.6 \mathrm{mg} / \mathrm{g})$ (Figure 3). Therefore the larva can be considered a very good source of carbohydrate.

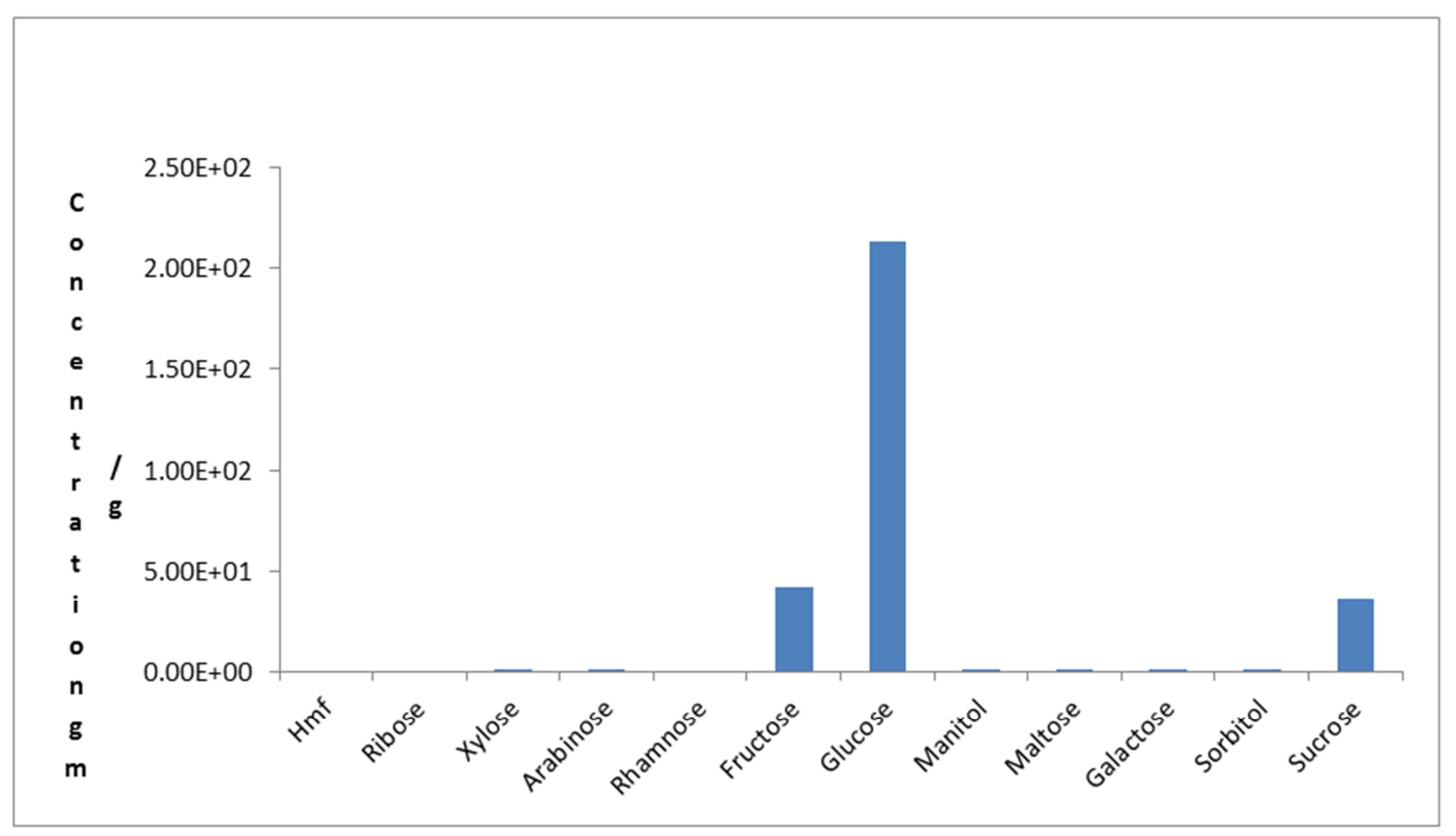

Figure 3. Carbohydrate composition of Rhynchophorus phoenicis larva.

Footnote to explain abbreviations:

(Hmf $=5$-hydroxymethylfurfural, Rib=Ribose, Xyl=Xylose, Ar=Arabnose, Rh=Rhamnose, Fr=Fructose, Gl=Glucose, $\mathrm{M}=$ Manitol, $\mathrm{M}=$ Maltose, $\mathrm{Ga}=$ Galactose, $\mathrm{So}=$ Sorbtol and $\mathrm{Su}=$ Sucrose) 


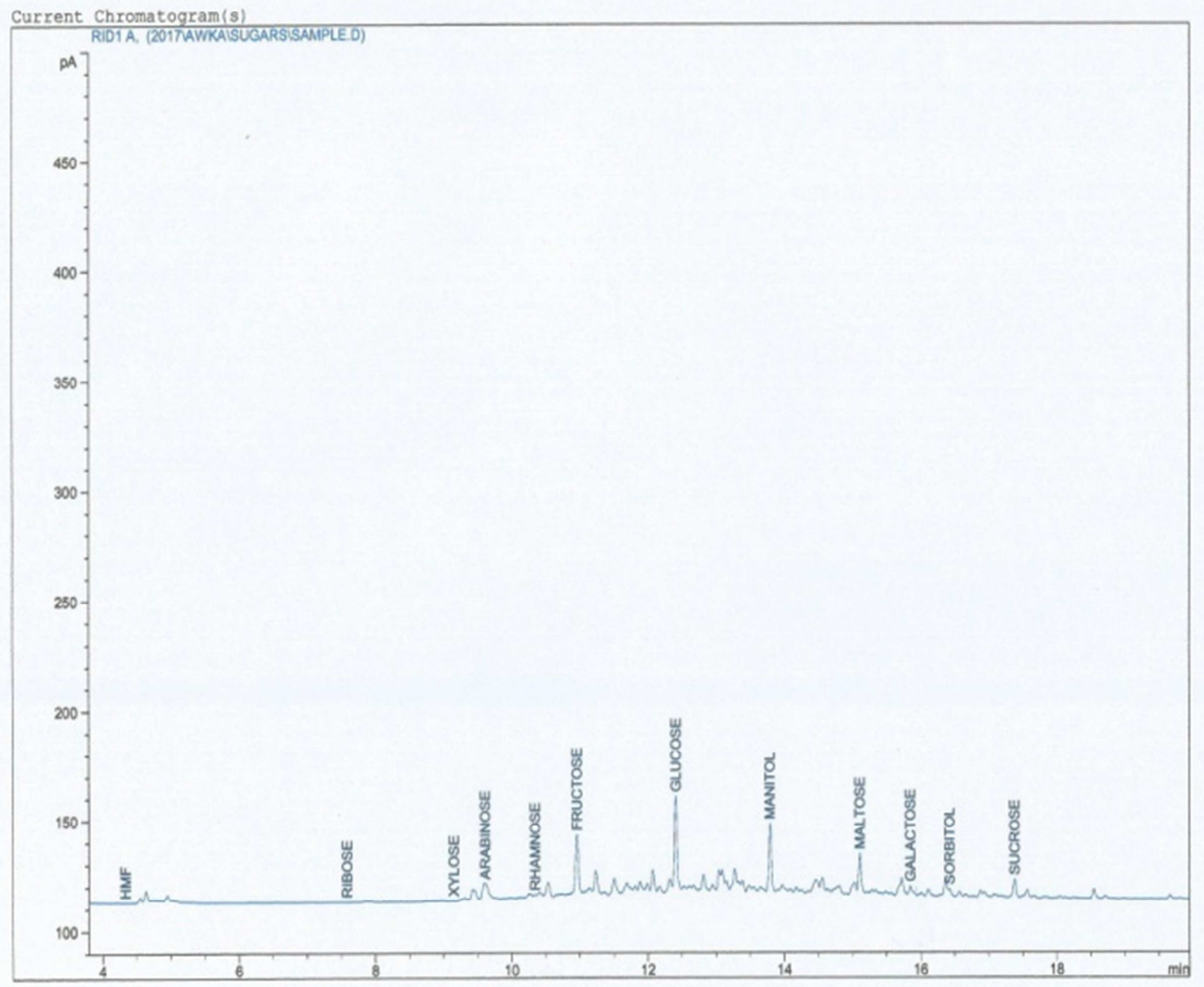

Figure 4. The chromatograms of the carbohydrate composition of the larva.

\section{Conclusion}

The high concentrations of various essential and nonessential amino acids as well as the sulfur containing amino acids are adjudged very beneficial in meeting human requirements for amino acids that are indispensable. This indicates that palm weevil larvae can act as dietary amino acid supplement in developing countries where it is readily available, in contrast with animal protein, which is quite expensive, and can also be included in both human and livestock diets as a source of animal protein.

\section{References}

[1] Opara, M. N., Sanyigha, F. T., Ogbuewu, I. P. and Okoli, I. C. (2012). Studies on the production trend and quality characteristics of palm grubs in the tropical rain forest zone of Nigeria. Journal of Agricultural Technology; 8 (3): 851-860.
[2] Köhler, R., Kariuki, L., Lambert, C. and Biesalski, H. K. (2019). Protein, amino acid and mineral composition of some edible insects from Thailand. J Asia Pac Entomol; 22: 372378. https://doi.org/10.1016/j.aspen.2019.02.002.

[3] Köhler, R., Irias-Mata, A., Ramandey, E., Purwestri, R. and Biesalski, H. K. (2020). Nutrient composition of the Indonesian sago grub (Rhynchophorus bilineatus). International Journal of Tropical Insects Science.

[4] De Foliart, G.(1992). A concise summary of the general nutritional value of insects. Http://www.foodinsects.com/.InsectsasHumanFood.Htm.

[5] Choon-Fah, J. B., Chin-Chin, E., Pang-Hung, Y. and Amarta lingam, R. (2008). Growth performance of the red-striped weevil Rhynchophorus Schach Oliv. (Insecta: Coleoptera: Curculionidae) on meridic diets. American Journal of Agriculture and Biological Science; 3: 402-409.

[6] Ekrakene, T. and Igeleke C. L. (2007). Microbial isolates from the roasted larva of the palm weevil (Rhynchophorus phoenicis [Fabr.]) from Edo and Delta states of Nigeria. American Journal of Biology and Applied Science, 1: 763-768. 
[7] Ekpo, E. K. and Onigbinde O. A. (2005). Nutritional potentials of the larva of Rhynchophorus phoenicis (F). Pakistan Journal of Nutrition; 4 (5): 287-290.

[8] American Chemical Society, (1980). Subcommitee on enviromental analytical chemistry. Guidelines for data acquisition and data quality evaluation in enviromental chemistry. Analytical Chemistry, 52: 2242-80.

[9] Elkin, R. G. and Griffith, J. E. (1985). A mino acid analysis of feed stuffhy droly sates by cation exchange high performance liquid chromatography. Journal of Association of Official and Analytical Chemistry. 68 (5): 1028-32.

[10] Anumula, K. R. (1994). Quantitative determination of monosac charidesingly coproteins by high-performance liquid chromatography with highly sensitive fluorescence detection. Analytical Biochemistry, 220: 275-283.

[11] FAO,(1972). Amino acid content of food and biological data on proteins, Report of Food and Agriculture Organisation /United Nations Joint Committee, Rome, p116.

[12] Romano, C., Corsetti, G., Flati, V., Pasini, E., Picca, A., Calvani, R., Marzetti, E. and Dioguardi, F. S. (2019). Influence of diets with varying essential/nonessential amino acid ratios on mouse lifespan. Nutrients 11 .

[13] Ogbuagu, M. N., Ohondu, I. and Nwigwe, C.(2011). Fatty acid and a mino acid profiles of the larva of raffia palm weevil: Rhynchophorus phoenicis. The Pacific Journal of Science and Technology; 12 (2).

[14] FAO/WHO/UNU,(1991)."Protein Quality Evaluation.” Food and Agricultural organization of the United Nations: Rome, Italy.

[15] Thangadurai, D.(2005). "Chemical Composition of and nutritional potential of Vignauguiculataspp. Cylidrica (Fabaceae)."Journal of Food Biochemistry. 28: 88-98. 